Eugenio González R.

\title{
Ceniza del tiempo
}

1

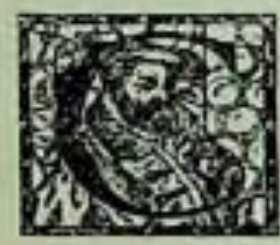

ENIZA del tiempo: el sedimento casi imperceptible y amargo que van dejando estas horas inútiles, vividas al azar, sin saber cómo ni para qué; lo que fué un día hoguera de terribles ansias calcinando las entrañas y los propósitos mejores; puñado de sollozos blasfemos que quieren esparcirse y marchitarlo todo, como ofro oloño: He aqui, amigos míos, la pobre riqueza que nos queda. Desde la soledad tendemos el arco maldito, y la flecha del arco busca vuestros corazones bienaventurados. Que ella atraviese los muros del misterio: que ella rompa el silencio y el odio que nos apartan, que ella consiga abrir el surco dolorido donde han de reposar estas palabras hoscas, ásperas, oscuras...

Después de todo, lo único importante para nosotros somos nosotros mismos. Rasguñamos, impacientes, cada día, la torva corteza que envuelve el secreto de nuestro corazón. A solas, nos preguntamos qué somos y qué deseamos. Estas preguntas martillean nuestras horas. Estas preguntas abren un sepulcro a todo sueño de serenidad y de victoria sobre la vida. Porque sólo un sueño-cualquier sueño, malo o bueno-salva... De vez en cuando una vislumbre, un pedazo de música robado al silencio circundante y enorme, un roce de alas desconocidas, allá, en lo hondo del ser, donde la conciencia se duerme embriagada por una inefable realidad sin forma. $\mathrm{Y}$ eso, pequeño, débil, impreciso; humo de una hoguera oculta que nadie vió subir, en la niebla.

$\mathrm{Y}$ asi también, humo vano, las mejores palabras, las que temblaron, 
al borde de los labios, cohibidas, en los momentos definitivos, las que se pudrieron después en el surco abandonado de la soledad. Sin embargo. en esta pobreza de sabernos solos, mendigos orgullosos de una ternura que no viene, algo-¿qué: quién?-nos dice que nosotros somos todo. Que recogemos las dispersas y amargas voces del mundo, el latido sediento de la tierra negra, las estrellas que decoran, cintilando los senos de la noche, el sufrimiento de la hierba pisoteada que se crispa hacia el sol. Todo... A pesar de todo eso que es nuestro, la verdad, nuestra verdad, nos huye. La seguimos buscando afuera, en el vacío sin medida con fiebre, con rabia. Y cuando el cansancio de las vanas jornadas nos arroja como despojos gemebundos en los recodos, siempre, royéndonos el alma y la vida, la misma pregunta: ¿Quién soy? ¿Quién soy?...

\section{III}

Todo se nos va, todo se nos va: pero quedamos nosotros, despojados, inermes, crucificados, por la culpa de sobrevivir a las cosas idas, en el recuerdo. Con los ojos tendidos, suplicantes, hacia horizontes que siempre huyen. ¿Quién dijo jamás la pobreza infinita de nuestro deseo? ¿Quién pudo detener la marca de ansia y de rencor que ahogó nuestras palabras en la soledad de la derrota?... Y luego, esta tenacidad de la ternura humana que sigue buscando en los sótanos del sueño la antigua tristeza y la antigua sonrisa, después, mucho después que la lámpara del amor en fuga cesó de brillar para nosotros, perdida, allá, lejos, en el último recodo...

\section{IV}

Este pueblo en sus casas bajas, sucias, es como una tumba grande abierta hacia lo desconocido, llena de oscuras germinaciones sin sentido. de vidas decrépitas y polvorientas. Una pesadumbre de resignación envuelve como otra atmósfera las almas y las cosas. El mañana no tiene importancia: la cuestión es tener, ahora, un poco de paz, y darse a todo con indiferencia y humildad para que asi se cumplan los designios inescrutables. Y ahí van esos pobres hombres con su andar reconcentrado y esa sonrisa estúpida, despegada, pronta a caer como un harapo inútil. padres e hijos se dan ánimos, se apoyan en su común timidez ante el destino inseguro. Nosotros trabajamos para ustedes, - mascullan los pa- 
dres,- trabajen ustedes para los que vienen. La vida cuesta llanto, sudor. sangre. Ser feliz es sólo esto: Amar el dolor que Dios nos da, con el pan, cada día.... Y así es. Las fuertes pasiones. los vigorosos y bellos impetus arrinconados por la vida precaria en el fondo de las almas, acaban por dormirse, para siempre, a veces. Y pasa el invierno; cesa el repiqueteo de sus lluvias tenaces en las techumbres; vuelve la primavera, el cielo limpio, el plácido verdor de la naturaleza. Más tarde, otra vez el invierno, otra vez la lluvia...

\section{V}

Desde hace una efernidad-nadie podría decir cuando comenzó esto,-las mismas casas, los mismos rostros, el mismo pedazo opaco de paisaje y de vida a nuestro alrededor. Sin embargo, nos vamos, nos vamos cada día, cada hora, cada instante. Es un darse continuo al tiempo y al misterio: ineludible como el rodar del agua por la pendiente de la colina. Casi no nos damos cuenta de ello y es que vivimos en una somnolencia cansada, apenas lúcidos para la migaja de sol que abandona el crepúsculo en la ventana. Por ella sabemos que otro día se va, que otra noche viene. Aquí, entre estas cuatro paredes, estamos como en todo el mundo. Mas allá de ellas, los campanarios, las esfrellas, las pasiones, forman una sola mancha odiosa que se dilata hasta lo infinito. Ayer no más, es cierto, llamamos hermanos a los ofros y. nuestro corazón, acurrucado en un regazo de amor, creyó en lo imposible. Ahora nó. Ahora, amigos, se vive hacia adentro. Las ventanas sobre el jardín están cerradas. Y, bajo la lámpara, envejecidos por la sombra que acecha, sentimos caer la lluvia, afuera, sobre los árboles empobrecidos y las calles solas.

\section{VI}

Bajo el ala cenicienta de los crepúsculos-tú lo recuerdas, alma escondida,- - nos perdiamos por la ciudad huraña con el bagaje fierno y a la vez terrible de nuestro silencio: confusas visiones prolongadas de perspectivas inefables, dulzura de sabernos aislados y próximos en medio de la naturaleza y de la vida. Junto a mi brazo, su brazo palpitaba, y era su sonrisa. la limosna tímida de su sonrisa de veinte años. lo único que distinguian mis ojos oscuros de suplicante. Después, cuan- 
do llegaba el momento de la cotidiana separación, nos ibamos entristecidos y medrosos. Porque sabiamos que un dia cualquiera, en la infinita paz de un hogar, mirándonos los rostros agrietados de angustia o, como ahora, vencidos por el tiempo. la distancia y el misterio, habriamos de sollozar sobre nuestro corazón, como sobre una tumba.

\section{VII}

Alguien ha abierto una ventana que da hacia los campos. Arrebujados en una neblina azulesca-luz de luna y distancia-los álamos forman una franja oscura al pie de la colina. Más cerca, desde las heredades circundantes, surcadas en todas direcciones por el agua de riego. sube, calmoso, el canto agrario de los sapos. Todo se concierta en una amodorrada armonía que es más de muerte que de vida, a pesar del vigor de las raíces ocultas, de la fragancia mojada de la tierra, del aleteo de los follajes dorados ya, casi amarillos, porque este viento trae puñado de ofoño. Sobre los párpados cansados, una sombra se va deslizando en visiones e indecisas figuras: acaso toman cuerpo las preguntas que nadie respondió, acaso los deseos que nadie pudo entrever a través de las palabras de todos los días. Y es que talvez el corazón de la noche quisiera libertarse de sus límites de silencio, y verter en un extraño canto humano el aluvión de sus ansias contreñidas en la madeja de las leyes ignotas. O bien, hay algo que no comprendemos del todo aquí, en el hervor delirante de nosotros mismos, algo que parece venir de una playa abandonada: ola de ternura que desgarra, que ahoga como una mano crispada de furia, que embriaga, mejor, como un viejo vino. Ello es que esta noche perdida entre las infinitas noches de la vida es como ninguna: tiene ojos azules abiertos en una dádiva de claridad y de perdón, tiene una sonrisa que extiende a la tierra, dorada y suave como el alba, como el otoño, y tiene una voz tan serena, tan rica de lejania y de misterio, que para escucharla avaramente, ahora, que hasta los árboles parecen dormidos, alguien ha abierto una ventana que va hacia los campos.

EUGENIO GONZALEZ R. 